\title{
GRADATION CRITERIA FOR EXPERIMENTALLY INDUCED PERIAPICAL LESIONS IN MICE
}

Velickovic Milena ${ }^{1}$, Mitrovic Slobodanka ${ }^{2}$, Kanjevac Tatjana ${ }^{3}$, Radosavljevic Gordana ${ }^{1}$, Pavlovic Sladjana ${ }^{1}$, Lukic Aleksandra ${ }^{4}$ ${ }^{1}$ Department of Immunology, Center for Molecular Medicine and Stem Cell Research, Faculty of Medical Sciences, University of Kragujevac, Serbia ${ }^{2}$ Department of Pathology, Center for Molecular Medicine and Stem Cell Research, Faculty of Medical Sciences, University of Kragujevac, Serbia ${ }^{3}$ Department for Preventive and Pediatric Dentistry, Faculty of Medical Sciences, University of Kragujevac, Serbia

${ }^{4}$ Department of Endodontics, Faculty of Medical Sciences, University of Kragujevac, Serbia

\section{GRADACIONI KRITERIJUMI EKSPERIMENTALNIH PERIAPEKSNIH LEZIJA KOD MIŠEVA}

\author{
Veličković Milena ${ }^{1}$, Mitrović Slobodanka ${ }^{2}$, Kanjevac Tatjana ${ }^{3}$, Radosavljević Gordana ${ }^{1}$, Pavlović Slađana ${ }^{1}$, Lukić Aleksandra ${ }^{4}$ \\ Odsek za imunologiju, Centar za molekularnu medicinu i istraživanje matičnih ćelija, Fakultet medicinskih nauka, Univerzitet u Kragujevcu, Srbija \\ ${ }^{2}$ Odsek za patologiju, Centar za molekularnu medicinu i istraživanje matičnih ćelija, Fakultet medicinskih nauka, Univerzitet u Kragujevcu, Srbija \\ Odsek za preventivnu i dečiju stomatologiju, Fakultet medicinskih nauka, Univerzitet u Kragujevcu, Srbija \\ ${ }^{4}$ Odsek za endodonciju, Fakultet medicinskih nauka, Univerzitet u Kragujevcu, Srbija
}

Received / Primljen: 20.05.2012.

Accepted / Prihvaćen: 20.08.2013.

\section{ABSTRACT}

A periapical lesion occurs as periapical tissue reacts to a dental pulp anaerobic infection. This phenomenon may result from carious lesions, tooth fractures, or iatrogenic and other circumstances that allow for bacteria to penetrate into the pulpal tissues.

Objectives: This study histologically evaluated experimentally induced periapical lesions using the Autodesk AutoCAD 2010 software. Additionally, based on the amounts of alveolar bone destruction sizes in the mouse model regions, a proposed experimental periapical lesion gradation criterion was created.

Methods: Twelve $B A L B / c$ mice were utilizised in a periapical model, whereby their mandibular right first molars were coronally opened, allowing for pulp exposure to host oral bacterial flora. These mice were sacrificed two and four weeks following pulp exposure. Following each sacrifice, hemi-mandibles were fixed in $4 \%$ paraformaldehyde, decalcified in 3\% formic acid, embedded in paraffin and cut into 4- $\mu m$-thick sections. The sections were stained with haematoxylin-eosin and examined with light microscopy (40x). Section images that included the mandibular first molar distal roots and passed through the apical foramens were selected for analysis. The periodontal ligament sizes were measured using the Autodesk AutoCAD 2010 software.

Results: There was a highly significant lesgion size difference at the two different time points following the lesion induction ( $p=0.002)$. The periapical lesions were classified according to periapical bone resorption sizes. We determined the values of quartiles (25\% and $75 \%$ ) and median areas (50\%) of the mean lesion values at both experimental periods. These data enabled for scoring of the lesions with grades from 1 to 4. The area of the normal periodontal ligament space was assigned with a grade of 0 .

Conclusion: This newly designed gradation criteria represent a significant advantage compared with the previous descriptive methods used for determining periapical tissue bone destruction levels. It The criteria achieves this advantage by excluding subjectivity, facilitating a numerical presentation of the data and reducing the possibility of making errors by using the highly availably Autodesk AutoCAD 2010 software.

Keywords: Periapical lesion, inflammation, gradation

\section{SAŽETAK}

Periapiksna lezija predstavlja reakciju periapeksnog tkiva na anaerobnu infekciju pulpe, koja najčešće nastaje kao posledica karijesa, frakture zuba, dejstva jatrogenih $i$ drugih faktora koji omogućavaju prodor mikroorganizama u komoru puple.

Ciljevi: Izračunati površine eksperimentalno indukovanih periapeksnih lezija korišćenjem programa Autodesk AutoCAD 2010, i na osnovu veličine prostora resorbovane alveolarne kosti u periapeksnom regionu predložiti kriterijume za gradaciju ovih lezija.

Metode: $B A L B / c$ miševima otvorena je pulpa prvog mandibularnog molara $(n=12)$. Miševi su žrtvovani dve $i$ četiri nedelje nakon indukcije lezija, izolovane su desne hemi-mandibule, fiksirane u $4 \%$ paraformaldehidu, dekalcifikovane u 3\% mravljoj kiselini i ukalupljene u parafin. Zatim su napravljeni preparati debljine $4 \mu \mathrm{m}$. Nakon bojenja hematoksilin-eozinom, preparati su posmatrani svetlosnim mikroskopom (40x), fotografisani, $i$ analizirani korišćenjem programa Autodesk AutoCAD 2010. Za analizu su izabrani preparati koji obuhvataju distalni koren prvog mandibularnog molara i prolaze kroz apikalni foramen.

Rezultati: Postojala je visoka signifikantna razlika izmedu površina periapeksnih lezija izmerenih $u$ dva razlicita vremenska termina nakon indukcije lezija $(p=0,002)$. Određivanje vrednosti kvartila (25\% i 75\%) i medijane (50\%) od prosečne vrednosti svih lezija omogućilo je gradiranje periapeksnih lezija brojevima od 1 do 4. Prostoru normalnog periodontalnog ligamenta dodeljen je gradus 0 .

Zaključci: Novo-dizajnirani gradacioni kriterijumi predstavljaju značajnu prednost u odnosu na do sada opisane deskriptivne metode za određivanje stepena destrukcije kosti u periapeksnom regionu, jer isključuju subjektivnost, redukuju mogućnost pravljenja greški $i$ olakšavaju numeričku prezentaciju podataka.

Ključne reči: Periapeksna lezija, inflamacija, gradacija 


\section{INTRODUCTION}

A dental periapical lesion occurs as the periapical tissue reacts to anaerobic infections in the dental pulp [1]. The dental pulp is protected from oral cavity microorganisms by enamel and dentine. The exposure of the dental pulp to microorganisms and their products, as a consequence of carious lesions, tooth fractures, traumatic operative dental procedures, or iatrogenic and other circumstances, can trigger local inflammatory responses [2]. The progression of such infections and inflammation may result in pulp necrosis. Subsequently, the periapical tissues may be affected following the egress of the microorganisms, usually from an infected root canal [3]. The host's response to these infections appears to be similar to the response to bacterial infections elsewhere in the body, with the additional feature that the alveolar bone surrounding the dental root apex often becomes resorbed [4]. This response is characterised by the persistent migration of inflammatory cells to the infected sites [5]. Together with the resident connective tissue cells, the migrated cells release several mediators, which contribute to infection progression curtailment. This inflammatory process, however, might also mediate the development of surrounding tissue lesions as well as bone resorption [6].

Although many studies have been conducted aiming to investigate experimental periapical lesion kinetics, a precise gradation criterion of these lesions has yet to be established. Periapical lesions are known to expand most rapidly two weeks following pulp exposure to pathogens (active phase), with lesion enlargement occurring at a slower rate thereafter (chronic phase) [7]. Additionally, the periapical bone destruction levels were described as small, increased or extensive, without any explanation for these categories $[8,9]$.

The aims of this study were to evaluate any associations between changes in periapical tissue alveolar bone resorption levels and different lesion grades, as well as to evaluate the prevalence of these grades. For that purpose, the mandibular first molar dental pulps were exposed in BALB/c mice. As has been observed in previous studies using this mouse strain, periapical lesions increase to their maximum size 2-4 weeks following pulp exposure [3]. Herein, we evaluated the periapical bone resorption amounts at these time points using the AutoDesk AutoCAD 2010 software. Autodesk AutoCAD is a computer-aided design program that is traditionally used for calculations and design in architecture and engineering [10]. The concept of using AutoCAD to precisely calculate surface areas and volumes is a relatively new method used in dental studies.

\section{MATERIALS AND METHODS}

\section{Animals}

We used 6- to 8-week-old female wild type (WT) $\mathrm{BALB} / \mathrm{c}$ mice for the induction of periapical lesions. WT $\mathrm{BALB} / \mathrm{c}$ mice were kindly provided by the Military Medi- cal Academy (MMA, Belgrade, Serbia). All animals were maintained in our animal facilities (Vivariums of the Faculty of Medical Sciences, University of Kragujevac). Mice were housed in a temperature-controlled environment with a $12 \mathrm{~h}$ light/12 $\mathrm{h}$ dark cycle and were administered standard laboratory chow and water ad libitum. All animals received humane care, and all experiments were approved by the Animal Ethics Committee of the Faculty of Medicine, University of Kragujevac, Serbia.

\section{Periapical lesion induction}

Periapical lesions were induced by exposing the rightsided mandibular first molar pulp to the host oral bacterial flora, as previously described [11]. Mice were anesthetised with ketamine hydrochloride $(60 \mathrm{mg} / \mathrm{kg}$ of body weight) and xylazine $(10 \mathrm{mg} / \mathrm{kg}$ of body weight) in sterile phosphate-buffered saline (PBS) by intraperitoneal injection, and mounted on a jaw-retraction board. The mandibular molar pulps were exposed using a high-speed electric dental handpiece (W\&H Dentalwerk, Búrmoos, Austria) with a no. $1 / 4$ round carbide bur. The exposure size was approximately equivalent to the bur diameter. The pulp chambers were opened until the entrances of the canals could be visualised and probed with a no. 08 endodontic file. Exposed teeth were left open to the oral environment for $14(n=6)$ or 28 days $(n=6)$. The non-exposed teeth served as negative controls.

\section{Histology evaluation}

The mice were sacrificed by diet hylether asphyxiation, and the mandibles were then isolated and fixed in $4 \%$ paraformaldehyde for $24 \mathrm{~h}$. The fixed mandibles were decalcified in 3\% formic acid for $24 \mathrm{~h}$ and then embedded in paraffin. Tissue blocks were cut in $4 \mu \mathrm{m}$ longitudinal serial sections. Every fourth sample was mounted and stained with haematoxylin and eosin (H\&E).

\section{Semi-quantitative measurements of the periapical lesions}

The sections that included the mandibular first molar distal roots and passed through the apical foramen (or close to it) were selected for semi-quantitative lesion size measurements. The distal roots were used for the analyses because these roots were better preserved and because the sectioning was more parallel to the long axes of these roots than of the mesial roots. The area of the periapical region was traced surrounding the apical third of the roots were traced with the Paint program (Fig. 1A). Measurements were made using the Autodesk AutoCAD 2010 software. Each photo was converted into a newly created Autodesk AutoCAD 2010.dxf file using the Img2CAD program, which is recognized by the Autodesk AutoCAD 2010 software. As this conversion is not always perfect, we had to make minor corrections 

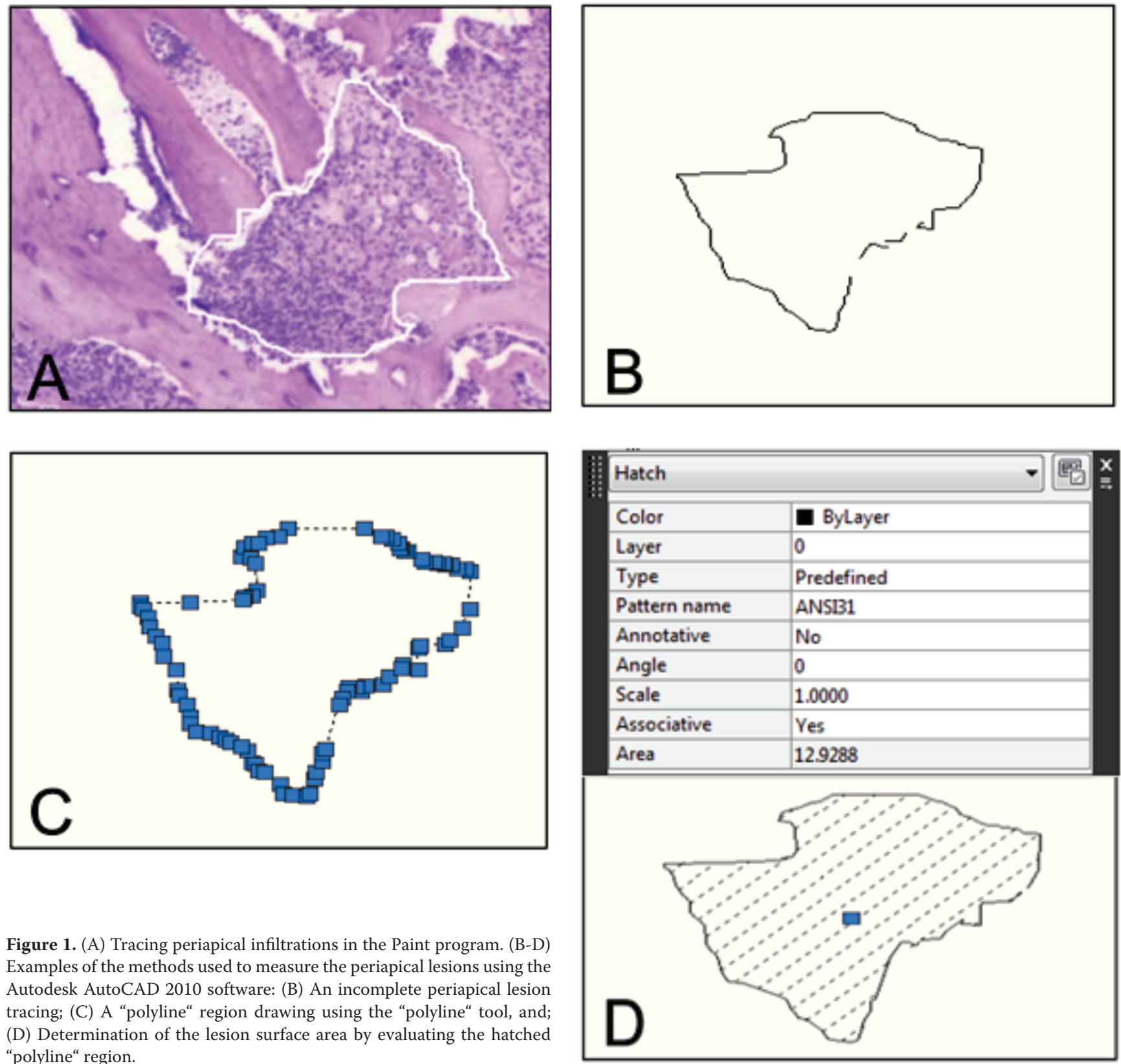

Figure 1. (A) Tracing periapical infiltrations in the Paint program. (B-D) Examples of the methods used to measure the periapical lesions using the Autodesk AutoCAD 2010 software: (B) An incomplete periapical lesion tracing; (C) A "polyline" region drawing using the "polyline" tool, and; (D) Determination of the lesion surface area by evaluating the hatched "polyline" region.

to the traced lesions after opening the files in AutoCAD to obtain a closed area whose surface could be calculated. Additionally, by using the "polyline" tool, we were able to draw the parts of the lesions that were not recognized by the program. Thus, we were able to connect the open ends of the lesions (Fig. 1B) and obtain "polyline" regions representing the periapical lesions (Fig. 1C). Then, we used the "Hatch" tool and within it selected the "Add: Select objects" option to mark these "polyline" regions. We determined the values of the drawn regions (Fig. 1D) by selecting the hatch area (by double clicking on the ENTER key). Prior to the determination of these areas, we established the scale bar values in the Autodesk AutoCAD 2010 software because the real surface of the periapical lesions was actually a ratio of these drawn regions, whereby the scale bar was multiplied by

the square of the real value of the scale bar (scale bar = $100 \mu \mathrm{m})$. The stock value of the Autodesk AutoCAD 2010 scale bar was 1 (Scale = 1; Fig. 1D); therefore, it was not difficult to determine this ratio.

\section{Statistical analyses}

All measurements were presented as mean values \pm SEM. Data were analysed using the SPSS statistical program, version 13. The distribution normality was assessed with the Shapiro-Wilk test. The study population did not follow a normal distribution; therefore, we determined significant differences in periapical lesion areas at two different time points using the Wilcoxon Rank Sum test. The results were considered significantly different if $\mathrm{p}<0.05$ and highly significantly different if $\mathrm{p}<0.01$. 

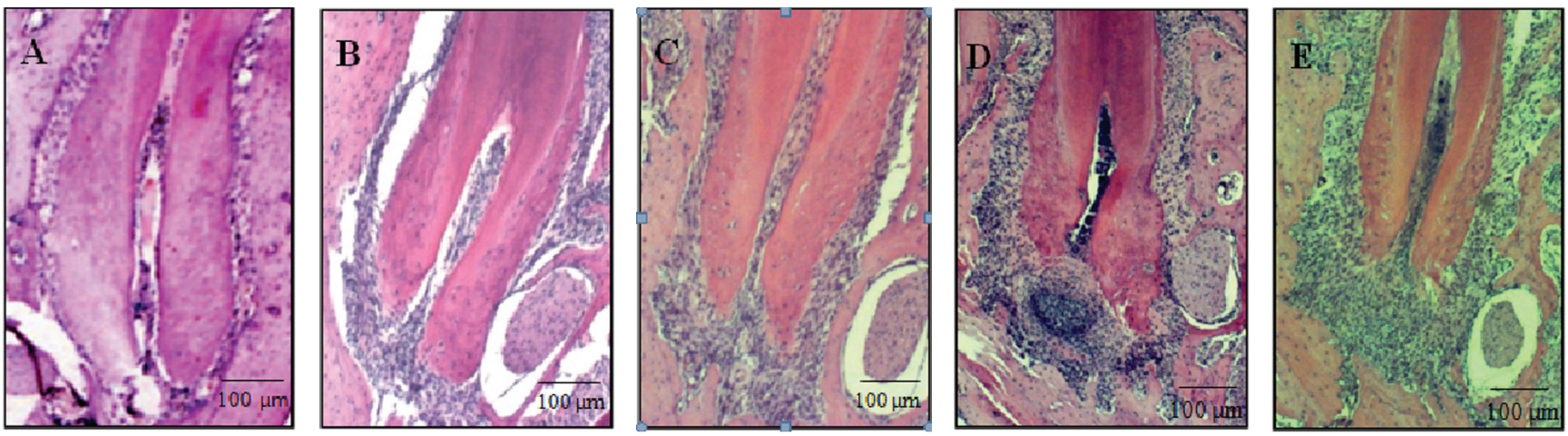

Figure 2. Histological findings. Representative haematoxylin-eosin stained histological sections: (A) Grade 0, (B) grade 1, (C) grade 2, (D) grade 3 and (E) grade 4 (Slides were evaluated with an Olympus BX51 microscope at 40X original magnification, scale bar $=100 \mu \mathrm{m}$ ).

\section{RESULTS}

\section{Histological findings}

Two weeks after pulp exposures, necrosis was observed in the upper half of the pulpal tissue. Additionally, slight or moderate inflammatory cell infiltration was observed in the lower half of the pulpal and periapical tissues (Fig. $2 \mathrm{~B}$ and $2 \mathrm{C}$ ). Inflammatory cell infiltrates were mostly in the form of polymorphonuclear cell sheets. Occasionally, round mononuclear cells with large condensed nuclei and low amounts of cytoplasm were observed, as well as large kidney-shaped cells with abundant cytoplasm. These cells were morphologically consistent with lymphocytes and macrophages, respectively. At this time, periapical alveolar bone resorption was also evident and was accompanied by multiple resorption lacunae containing multinucleated osteoclasts (Fig. 3). It was also possible to observe cementum resorption in the periapical regions.

Four weeks after pulp exposure, the pulpal tissue became completely necrotic. Moreover, the periapical regions exhibited an increased amount of bone resorption (Fig. 2D and 2E). Additionally, abscesses were found around the root apexes, and severe inflammatory cell infiltration was

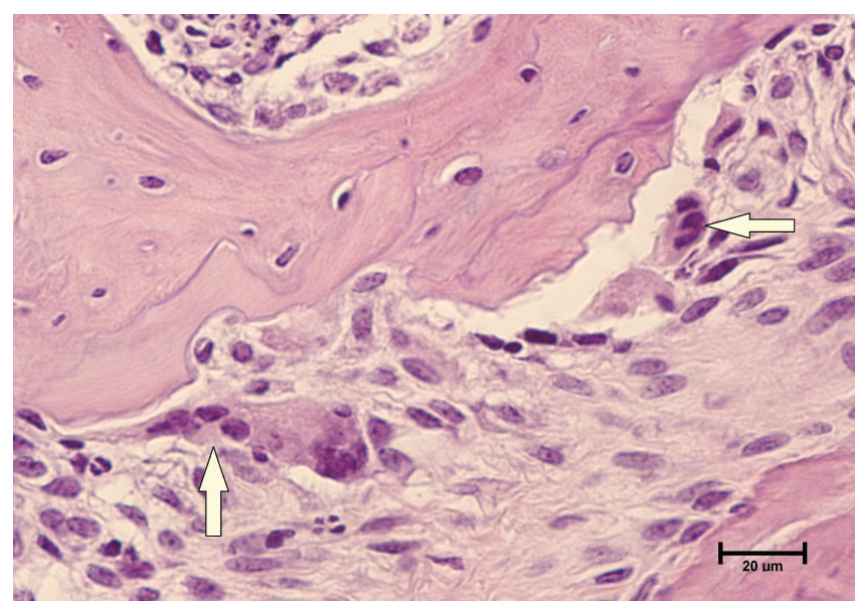

Figure 3. Periapical alveolar bone resorption was accompanied by multiple resorption lacunae containing multinucleated osteoclasts (haematoxylin-eosin stain; Nikon eclipse 50i; 600X original magnification; scale bar $=20 \mu \mathrm{m}$ ). observed in the periapical tissues. Fibrous granulomatous tissue was also observed peripheral to the infiltrates, with fibroblasts detected among the many neutrophils and other inflammatory cells. Cementum resorption was also noted.

No abnormalities were observed in the untreated mouse pulpal and periapical tissues (Fig. 2A).

Although there was some variability in lesion size and inflammatory cell content among the specimens, differences were observed between periapical tissue alveolar bone resorption levels and inflammatory cell infiltration levels between two and four weeks following pulp exposure.

\section{Histometric findings}

The extent of the periapical bone destruction was quantified by histomorphometry. Using the Autodesk AutoCAD 2010 software-aided graphical evaluation, we detected and calculated the surfaces of each periapical region in the mandibular first molar histological tissue sections. As shown in Fig. 4, a highly significant lesion size difference was observed at two different time points following lesion induction $(\mathrm{p}=0.002)$. The apical periodontal ligament area was significantly increased at 4 weeks (the periapical lesion "chronic phase") following pulp exposure when compared with the 2-week (the periapical lesion "active phase") time point.

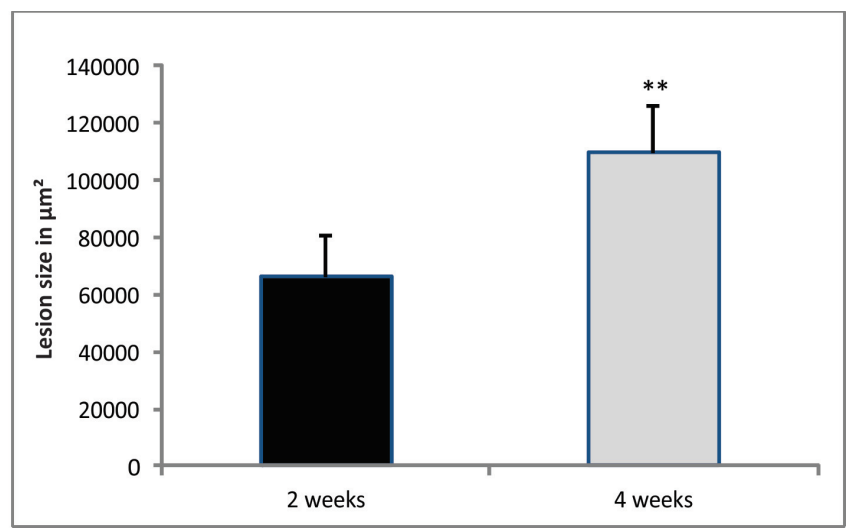

Figure 4. Histometric findings. Data are presented as the means \pm SEM of the mouse mandibular first molar lesion areas used in the study ( $\mathrm{n}=6$ at each time point; * $\mathrm{p}<0.05 ;{ }^{* *} \mathrm{p}<0.01$ ). 
Gradation of the experimentally induced mouse periapical lesions

The periapical lesions were classified according to the periapical bone resorption sizes. We determined the quartile $(25 \%$ and $75 \%)$ and median area (50\%) values of the lesion mean values at both experimental time points. These data enabled for scoring of the lesions with a grading system of 1 to 4 . Note that indicated control resorption areas represent the normal periodontal ligament space; therefore, this area was assigned a grade of 0 . Finally, based on the periapical region alveolar bone resorption sizes, we proposed the following gradation criteria for the observed periapical lesions in these experimental mice:

Grade 0: Normal histology. The area of the normal periodontal ligament space in uninfected mice. In these mice, the apical region size occupied less than 20,000 $\mu \mathrm{m}^{2}$ (Figure 1A).

Grade 1: Small periapical bone resorption. The apical region occupied less than 25 percent of the mean lesion value. The size of alveolar bone destruction in the periapical region was between 20,000- 42,672 $\mu^{2}$ in these mice (Figure 1B).

Grade 2: Moderate periapical bone resorption. The apical region occupied between 25-50 percent of the mean lesion value. The alveolar bone destruction size in the periapical region was between $42,672-85,344 \mu^{2}$ in these mice (Figure 1C).

Grade 3: Increased periapical bone resorption. The apical region occupied between $50-75$ percent of the mean lesion value. In these mice, the alveolar bone destruction size in the periapical region was between $85,344-128,016 \mu \mathrm{m}^{2}$ (Figure 1D).

Grade 4: Extensive periapical bone resorption. The apical region occupied more than 75 percent of the mean lesion value. The alveolar bone destruction size in the periapical region was more than $128,016 \mu \mathrm{m}^{2}$ in these mice (Figure $1 \mathrm{E}$ ).

Grade 1 was not a common finding, and comprised only $8.33 \%$ of the observed samples. The most prevalent findings, however, were the grades 2 and 3 lesions, which comprised $66.66 \%$ of the samples (Table 1 ).

\begin{tabular}{|l|l|l|}
\hline Periapical lesion grade & n & \% of the samples \\
\hline Grade 1 & 1 & 8.33 \\
\hline Grade 2 & 4 & 33.33 \\
\hline Grade 3 & 4 & 33.33 \\
\hline Grade 4 & 3 & 25 \\
\hline
\end{tabular}

Table 1. The prevalence of different experimentally induced periapical lesion grades.

\section{DISCUSSION}

The induction of periapical lesions in mice by the exposure of the right-sided mandibular first molar pulps to the host root canal bacterial flora is a useful method to study the pathogenesis of this condition $[1,12]$.

Although many studies have examined the histomorphometry of periapical lesions, there is no standardised and generally accepted method for the quantification of experimental periapical lesions in tissue sections [13, 14]. Because of this lack, we have presented a new histological method for the quantification of periapical bone destruction in tissue sections using the Autodesk AutoCAD 2010 software. AutoCAD is a computer-aided design (CAD) program, which maximises productivity by using powerful tools for creating, documenting, and sharing drawings $[15,16]$. With this technology, we measured the amount of periapical bone destruction by using the "polyline" method with the AutoCAD software. The results were highly specific and relevant to this histological analysis, confirming the reliability and accuracy of the Autodesk AutoCAD 2010 software for quantifying periapical bone destruction in this model.

The Autodesk AutoCAD software has been used in previous dental studies, including for root canal apical transportation evaluations, dentinal sealer penetration depth analyses and the determination of cemental and periodontal ligament thicknesses during various orthodontic tooth movements; however, there have been no reported studies regarding its use for experimental periapical lesion detection and quantification [17-20]. In line with our results, previous studies showed that the Autodesk AutoCAD software is reliable and can precisely calculate periapical region surface areas. Furthermore, the AutoCAD commands are very user friendly. These commands decrease the amount of time needed to conduct a task while also diminishing the amount of errors that occur. All of these findings confirm the validity of our semi-quantitative method for evaluating periapical lesions. Additionally, an important advantage of this method is the high availability of this software; therefore, this method could replace others that are more expensive and involve health risks, such as computed tomography and radiography $[7,21]$.

Until today, precise gradation criteria for evaluating experimentally induced periapical lesions had not been established. Previous studies used descriptive methods for determining periapical bone destruction levels (small, increased or extensive); therefore, the possibility of making an error was high $[8,9]$. To grade periapical lesions, we determined the quartile (25\% and $75 \%$ ) and median area (50\%) values of the mean lesion values. These data enabled for scoring of the lesions with grades from 1 to 4 . Subsequently, we summarised our histometric results and descriptive histological analyses to assign rational explanations for these grades. Because a normal periodontal ligament space represents ordinary histology, it was assigned with a grade of 0 . By using these gradation criteria, we obtained precise results, suggesting that the procedure described herein is more accurate at determining periapical region bone resorption levels than previous descriptive methods. The potential reasons for this improvement are exclusion of subjectivity, reduction of the possibility to make errors, facilitation of a numerical presentation of the data and provides an opportunity for researchers with an opportunity with an opportunity to reliably and precisely evaluate experimental periapical lesions. 


\section{ACKNOWLEDGEMENTS}

We thank Nikola Miljković, Miloš Milosavljević and Aleksandar Ilić for their excellent technical assistance. This work was supported by the grants from the Serbian Ministry of Science and Technological Development (OP 175071), Serbia.

\section{REFERENCES}

1. Yamasaki M, Kumazawa M, Kohsaka T, Nakamura $H$, Kameyama Y. Pulpal and periapical tissue reactions after experimental pulpal exposure in rats. Journal of Endodontics 1994; 20 (1): 13-17.

2. Sasaki H, Balto K, Kawashima N, Eastcott J, Hoshino K, Akira S, Stashenko P. IFN- $\gamma$ and IFN- $\gamma$-inducing cytokines IL-12 and IL-18 do not augment infection-stimulated bone resorption in vivo. Clinical and diagnostic laboratory immunology 2004; 11 (1): 106-110.

3. Fouad A.F, Acosta A.W. Periapical lesion progression and cytokine expression in an LPS hyporesponsive model. International Endodontic Journal. 2001; 34: 506-513.

4. Kawashima N. and Stashenko P. Exspression of boneresorptive and regulatory cytokines in murine periapical inflammation. Arch Oral Biol 1999; 44: 55-66.

5. Liapatas S, Nakou M, Rontogianni D. Inflammatory infiltrate of chronic periradicular lesions: an immunochistochemical study. International Endodontic Journal 2003; 36(7): 464-471.

6. Nair PNR. Apical periodontitis: a dynamic encounter between root canal infection and host response. Periodontology 2000 1997; 14(1): 121-148.

7. Stashenko P, Wang CY. Kinetics of bone-resorbing activity in developing periapical lesions. Journal of Dental Research 1991; 70(10): 1362-1366.

8. Balto K, Sasaki H, Stashenko P. Interleukin-6 deficiency increases inflammatory bone destruction. Infection and immunity 2001; 69(2): 744-750.

9. Teixeira RC, Rubira CM, Assis GF, Lauris JR, Cstari TM, Rubira Bullen IR. Radiological and histopatological evaluation of experimentally-induced periapical lesions in rats. Journal of Applied Oral Science 2011; 19(5): 500-504.

10. Volarevic A, Ljujic B, Volarevic V, Milovanovic M, Kanjevac T, Lukic A, Arsenijevic N. A new semiquantitative method for evaluation of metastasis progression. J BUON 2012; 17 (3): 585-590.
11. Yu SM, Stashenko P. Identification of inflammatory cells in developing rat periapical lesions. J Endod 1987; 13 (11): 535-540.

12. Yamasaki M, Kumazawa M, Kohsaka T, Nakamura H. Effect of methotrexate-induced neutropenia on rat periapical lesion. Oral surg oral med oral path 1994; 77: 655-661.

13. Huang GTJ, Do M, Wingard M, Park JS, Chuqal N. Effect of interleukin- 6 defficiency on the formation of periapical lesion after pulp exposure in mice. Oral surg oral med oral path 2001; 92 (1): 83-88.

14. Teles R, Wang CY, Stashenko P. Increased susceptibility of RAG-2 SCID mice to dissemination of endodontic infections. Infection and immunity 1997; 65(9): 3781-3787.

15. Letafatkar A, Amirsasan R, Abdolvahabi Z, Hadadnezhad M. Reliability and validity of the AutoCAD software method in lumbar lordosis measurement. J Chiropr Med 2011; 10: 240-247.

16. Volarevic V, Milovanovic M, Arsenijevic N, Lukic M. The new semi-quantitative method for determination of liver damage after Concavalin A administration. Ser J Exp Clin Res 2010; 11 (2): 45-48.

17. Duran-Sindreu F, Garcĺa M, Olivieri JG, Mercadé M, Morelló S, Roig M. A comparison of apical transportation between FlexMaster and Twisted Files rotary instruments. J Endod 2012; 38(7): 993-995.

18. Garcĺa M, Duran-Sindreu F, Mercadé M, Bueno R, Roig M. A comparison of apical transportation between ProFile and $\mathrm{RaCe}$ rotary instruments. J Endod 2012; 38(7): 990-992.

19. Ravindranath M, Neelakantan P, Karpagavinayagam K, Subba Rao CV. The influence of obturation technique on sealer thickness and depth of sealer penetration into dentinal tubules evaluated by computer-aided digital analysis. Gen Dent 2011; 59(5): 376-382.

20. Vikram NR, Senthil Kumar KS, Nagachandran KS, Hashir YM. Apical stress distribution on maxillary central incisor during various orthodontic tooth movements by varying cemental and two different periodontal ligament thicknesses: a FEM study. Indian J Dent Res 2012; 23(2): 213-220.

21. Oseko F, Yamamoto T, Akamatsu Y, Kanamura N, Iwakura Y, Imanishi J, Kita M. IL-17 is involved in bone resorption in mouse periapical lesions. Microbiol Immunol 2009; 53: 287-294. 